\title{
Wide Spread Use of Monoclonal Antibody would have Prevented Massive Death Rate from Covid-19 Infection
}

\section{Tapan K Chaudhuri* and Richard Hoffler}

Hampton, VA and San Antonio, TX, USA

*Corresponding Author: Tapan K Chaudhuri, Hampton, VA, USA.

E-mail: tkchaudhuri44@gmail.com

If the use of Monoclonal Antibody (MoAb) to COVID-19 saved the life of the President of the United States and several other people in his circle, then why are we not using the same therapy for everybody else. If we aggressively motivate to start the use of MoAb to COVID-19 infection, we can prevent a lot of deaths. It's a magic bullet, it's a cure.

MoAb to COVID-19 is a life saving measure when used in the early nasopharyngeal phase [1] of mild to moderate disease SARS-CoV-2. But patients are not offered the availability of this treatment as an option and many don't even know that this treatment exists. Lack of awareness of availability of this treatment, lack of aggressive motivation to use this treatment and the lack of easy accessibility to this drug are all attributable to high death rate of COVID-19 infection.

This therapy is most effective when given in the early nasopharyngeal phase [1] of the disease. This therapy requires to set up an isolated infusion room.

Institution of monoclonal antibody infusion in the early nasopharyngeal phase of the disease would prevent emergency room visit, hospitalization, ICU admission, Oxygen therapy, mechanical ventilation and death.

Millions of people who have died from COVID -19 infection were probably not aware that the MoAb therapy was an option in the early stage of their disease.

The monoclonal antibody against COVID-19 is manufactured by Regeneron company and essentially consists of two recombinant human MoAb - Casirivimab (1,200 mg) and Imdevimab (1,200
Received: January 27, 2021

Published: January 30, 2021

(C) All rights are reserved by Tapan $\mathbf{K}$

Chaudhuri and Richard Hoffler. mg) administered together after dilution with intravenous infusion solution over at least 60 minutes to patients (adults and children 12 years of age and older weighing at least $40 \mathrm{Kg}$ ) after positive COVID-19 test and within 10 days of symptom onset with mild to moderate COVID-19 infection who are at high risk of progressing to severe COVID infection \{bronchoalveolar phase [1]\} requiring ICU admission and mechanical ventilation. The MoAb treatment is not indicated in patients who are already hospitalized and on high flow oxygen therapy or mechanical ventilation.

In conclusion institution of MoAb therapy should be aggressively promoted for widespread use, thus saving many lives.

\section{Bibliography}

1. Chaudhuri TK and Hoffler Richard. "Early Therapeutic Intervention in COVID-19 Infection May Prevent Death". Acta Scientific Pharmaceutical Sciences 5.1 (2021): 94.

\section{Assets from publication with us}

- Prompt Acknowledgement after receiving the article

- Thorough Double blinded peer review

- Rapid Publication

- Issue of Publication Certificate

- High visibility of your Published work

Website: www.actascientific.com/

Submit Article: www.actascientific.com/submission.php Email us: editor@actascientific.com

Contact us: +919182824667 